Geological Survey of Greenland (GGU): data files comprising the ore reserves data base, all geological sections and mine maps, a collection of typical ore specimens and $23 \mathrm{~km}$ of drill cores. A complete set of surface exploration reports was already housed at GGU. Based on this collection of geological material it will be possible to continue studies of the Black Angel ores and possibly gain new understanding of the distribution of ore deposits in the area.

Outside the old mine area, lead-zinc prospects of Black Angel type mineralisation occur in four areas (Fig. 1). Three of these were drill tested, but all have been rejected as viable prospects by Greenex $A / S$. It is to be hoped that further research in the Black Angel records and continued exploration of the Mârmorilik Formation will ultimately result in renewed mining in the region.

Acknowledgements. Greenex A/S is thanked for the permission to publish production and ore reserve data. Mogens Lind and Peter R. Dawes are thanked for critical comments.

\section{References}

Alm, L., Christensen, K. \& Ekenberg, R. 1987: Room and pillar mining in Maarmorilik, Greenland. In Almgren, G., Berg, I. \& Matikainen, R. (ed.) Improvement of mine productivity and overall economy by modern technology, 895904. Rotterdam: A. A. Balkema.

Carmichael, A. J. 1988: The tectonics and mineralisation of the Black Angel $\mathrm{Pb}-\mathrm{Zn}$ deposits, central West Greenland. Unpublished thesis, Goldsmith's College, Univ. London, 371 pp.

Eklund, O. 1940: Marmorbrytningen på Nordvästgrönland. Tek. Tidsskr. Stockh. 70(2), 5-7.

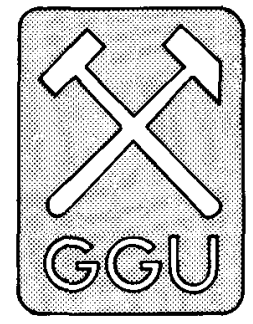

In the spring of 1990 the Greenland Home Rule administration initiated a project to evaluate the potential for ornamental stones in West and South Greenland, with support from the Geological Survey of Greenland
Garde, A. A. 1978: The Lower Proterozoic Marmorilik Formation, east of Mârmorilik, West Greenland. Meddr Grønland 200(3), $71 \mathrm{pp}$.

Grocott, J. \& Pulvertaft, T. C. R. in press: The Early Proterozoic Rinkian Belt of central West Greenland. Spec. Pap. geol. Ass. Can.

Henderson, G. \& Pulvertaft, T. C. R. 1987: The lithostratigraphy and structure of a Lower Proterozoic dome and nappe complex. Descriptive text to 1:100 000 sheets Mârmorilik 71 V.2 Syd, Nûgâtsiaq 71 V.2 Nord and Pangnertôq 72 V.2 Syd, 72 pp. Copenhagen: Grønlands geol. Unders.

Krauland, N. \& Söder, P. E. 1987: Determining pillar strength from pillar failure observation. Eng. Min. Jour. 188, 34-40.

Pauly, H. 1952: En undersøgelse af 'Sorte engel' ved Marmorilik, samt nogle bemærkninger om magnetkisforekomsterne $i$ Umanak distrikt i Nordgrønland. Meddr dansk geol. Foren. 12, 191-192.

Pedersen, F. D. 1980: Remobilization of the massive sulphide ore of the Black Angel mine, central West Greenland. Econ. Geol. 75, 1022-1041.

Pedersen, F. D. 1981: Polyphase deformation of the massive sulphide ore of the Black Angel mine, central West Greenland. Mineral Dep. 16, 157-176.

Sangster, D. F. 1990: Mississippi Valley-type and sedex leadzinc deposits: a comparative examination. Trans. Instn Min. Metall. Sect. B, 99, B21-B42.

Sølver, S. V. 1943: Flotationsfors $\emptyset$ g med bly-zink-pyrit-malm fra Grønland. Ingeniøren 38, K61-K64.

van der Stijl, F. W. 1990: Status of pillar reserves, August 1st 1990, Black Angel Mine and Nunngarut. Greenex A/S, intern. rep., $38 \mathrm{pp}$.

Wyllie, R. J. M. 1988: Boliden coaxes a few more years out of Greenland's Black Angel mine. Eng. Min. Jour. 189(2), 26-33.

B. T., Geological Survey of Greenland, Copenhagen.

\section{Ornamental stones in West and South Greenland}

\author{
Adam A. Garde, Christian Bugnon and \\ Jens Gothenborg
}

(GGU). The project was established in view of an interesting new development of the international ornamental stone market which might be exploited to diversify the economy and provide new job opportunities 
in Greenland. Ornamental stones are naturally occurring rocks with properties that make them suitable for decorative purposes, for example in the building industry, and as gravestones. In recent years there has been a worldwide increase in the use of hard rock types such as granite (expensive to cut and polish) which are common in Greenland, at the expense of marble which is cheaper to produce but much less resistant to acid rain, pollution and mechanical wear.

The objectives of the present survey were to localise exploitable occurrences of ornamental stones in the high-price category in the vicinity of existing towns and scttlements along the west coast of Greenland, to sample such localities, carry out test-cutting and polishing, and evaluate the results. The Danish cutting and polishing factory Danstein A/S kindly assisted with the latter objectives. The authors worked for four weeks in the field with local boats, in the following municipalities: Ilulissat/Jakobshavn, Aasiaat/Egedesminde, Maniitsoq/ Sukkertoppen, Nuuk/Godthåb, Narsaq, Qaqortoq/Julianehåb, and Nanortalik (Fig. 1). Two localities in and near Ammassalik in East Greenland, which had previously been visited by GGU geologists, were also tentatively evaluated. An unpublished report (Gothenborg \& Garde, 1990) contains background information about production of ornamental stones, exact locations and geological details from all visited localities, and an evaluation of the results of the project.

\section{Technical criteria for ornamental stones}

Several technical criteria have to be fulfilled by ornamental stones. Cutting and polishing of hard rocks with automated machines is expensive and requires that waste is minimal in order to be economical; this is only achieved by production using large, rectangular raw blocks. Large surface areas (about two square metres) of the finished cut and polished products are desirable for many purposes. Waste is also reduced in the production of smaller items if they can be cut from large regular blocks of rock. For these reasons the production of ornamental stones is severely affected by joints, which should not be present in more than three directions (preferably at right angles to each other), and should not be more closely spaced than $c .2-3 \mathrm{~m}$. The preferred size of blocks is $2-6 \mathrm{~m}^{3}$, i.e. blocks with weights between $c .5$ and 15 tons. The presence of joints often presents a major problem; ornamental stones which can be marketed at high prices are sometimes produced from quarries with as much as $90 \%$ waste due to adverse joint systems, which makes quarrying expensive and requires a large homogeneous resource.

Ornamental stones have to comply with certain speci-

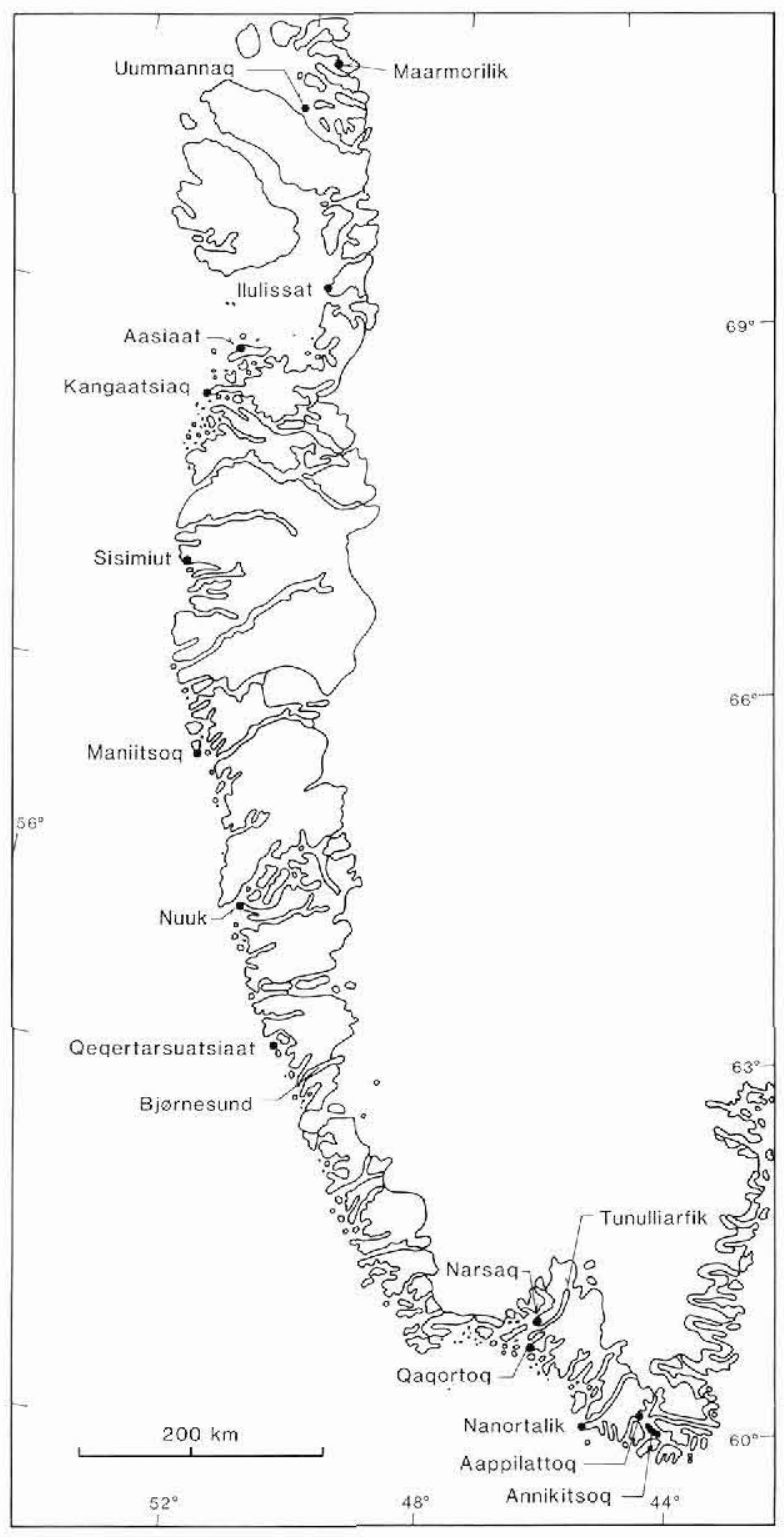

Fig. 1. Index map showing towns and fjords referred to in the main text.

fications of tensile and compressive strength, water absorption and frost resistance according to their use. Coarse-grained rocks are generally weaker and have to be cut in thicker sizes than finer-grained rocks. There should be no internal cracks, and other defects such as local alteration by radioactive minerals, inclusions or veins of other rock types are undesirable, unless these features occur very regularly and form an integral aspect of the rock. It is important for light-coloured rocks used in the open air that no iron-rich minerals are present which might weather and leave rusty spots. 
Pyrite and pyrrhotite in particular may cause such problems; iron oxides, especially ilmenite, are more resistant and their presence is sometimes permissible.

The value of ornamental stones depends on their size, colour and use, and is subject to change according to fashion. Strongly coloured rocks are most sought after. Jet black, red, multicoloured red/black, deep brown and white rocks used as gravestones can realise prices of up to $20000 \mathrm{D}$. Kr. (c. 3500 US \$) per cubic metre for large blocks. Less strongly coloured rocks used in the building industry cost around 2000 to $6000 \mathrm{D}$. Kr. (c. 350-1000 US \$) per cubic metre (large blocks). Smaller blocks down to one cubic metre in size are valued at only a fraction, per volume unit, compared to larger blocks.

\section{Previous initiatives}

Marble from the Proterozoic Marmorilik Formation has previously been quarried at two localities (on the island Agpat and at Maarmorilik in the Uummannaq district, central West Greenland), and exported to Denmark, but production closed down in 1972. In South Greenland the Proterozoic Igaliko sandstone, a conspicuously red-yellow spotted, fissile quartz sandstone, has been used locally for houses, and for a small outdoor square with stairs in Qaqortoq; a quarrying project was set up by a private company about 1980. J. Gutzon Larsen, Teknologisk Institut, Copenhagen, made short surveys of possible ornamental stones in South Greenland in 1985-86 in cooperation with Narsaq, Qaqortoq and Nanortalik municipalities. The town hall in Maniitsoq, which was completed in 1989, has indoor floors of locally quarried, unpolished granulite facies gneiss tiles with irregular greasy brown and dark greenish shades, which give an unusual and interesting effect; polished table tops in the same building are made of local granite, but contain a number of inherent defects. The Swiss company Intergeo-Exploration is currently evaluating a locality in the Proterozoic Ilímaussaq alkaline intrusion, in order to determine whether naujaite (see below) can be quarried profitably.

\section{Results of the present survey}

During the present survey large tracts of coastline around the specified towns were investigated (Fig. 1); see also Gothenborg \& Garde (1990). General information about the geology in most of the visited areas can be found in Kalsbeek \& Garde (1989) and Kalsbeek et al. (1990). The areas surveyed were selected where geological information available in GGU suggested the presence of suitable rocks, located in areas where quar- rying might be feasible not too far away from existing settlements. Our field work showed that the potential for ornamental stones in West Greenland is limited by two main factors. Firstly, there are in fact not many rocks in West Greenland which possess sufficiently strong and attractive colours and interesting textures, which also comply with production criteria such as size of the deposit, homogeneity, absence of inclusions, and lack of rusty spots. Secondly, the old Archaean to early Proterozoic basement in West Greenland contains ubiquitous and closely spaced joint systems in four or more directions. These joint systems are regional patterns rather than superficial relaxation joints found parallel to exposed surfaces which disappear with depth. The presence of regional joint systems severely restricts the potential for ornamental stones in West Greenland.

The only exception to the adverse regional joint pattern is found in the central to southern part of Nanortalik municipality towards the southern tip of Greenland, where widely spaced relaxation joints wrap around spectacular mountains of mid-Proterozoic rapakivi granite, and regional joints are few and widely spaced.

In West Greenland the survey covered: dolerite sills of probable Proterozoic age north of Ilulissat; various types of Archaean granitic gneisses in Ilulissat, Aasiaat, Maniitsoq and Nuuk municipalities; granulite facies gneiss in Maniitsoq town; and anorthosite in Sisimiut/ Holsteinsborg and Nuuk municipalities. In South Greenland, investigations included: grey Julianehåb granite; Igaliko sandstone near Narsaq; alkali granite and naujaite in the late Proterozoic Ilímaussaq intrusion; and rapakivi granite in the Nanortalik district. Previously collected samples of gneiss from Uumman-

Fig. 2. Cut and polished samples of various rocks from West, South and East Greenland. Scale approximately 1:3 (the coin on sample (10) has a diameter of $2.5 \mathrm{~cm}$ ). The samples are, from top left to bottom right: (1) banded leucogabbro/anorthosite, head of Bjørnesund; (2) naujaite with red eudialyte from the Ilímaussaq intrusion near Narsaq; (3) and (10) (top right and bottom left) grey rapakivi granite, the island Annikitsoq in Nanortalik district; (4) brownish grey granite, Ammassalik $\emptyset$, East Greenland; (5) Igaliko sandstone (natural split surface), Tunulliarfik north-east of Narsaq; (6) grey granitic gneiss with pink feldspar augen, c. $20 \mathrm{~km}$ north of Ilulissat; (7) salmon pink banded granitic gneiss from the island Akullit between Aasiaat and Kangaatsiaq; (8) brown granulite facies gneiss with a pale quartzo-feldspathic vein, Maniitsoq town; (9) brown hypersthene diorite, Ammassalik town, East Greenland; (11) light apple green granite from the Ilímaussaq intrusion near Narsaq; (12) creamy grey anorthosite, head of Bjørnesund. 



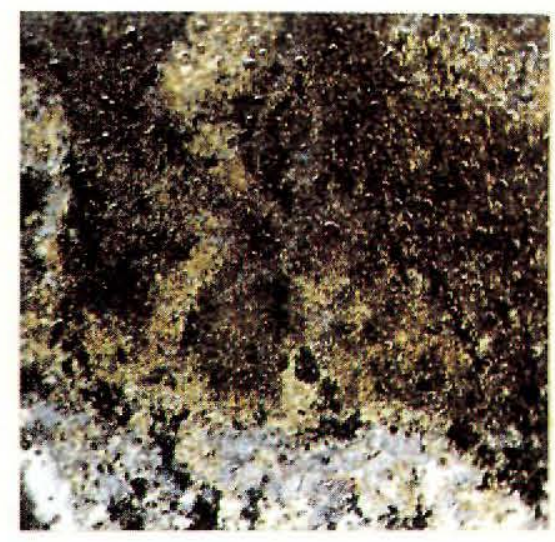

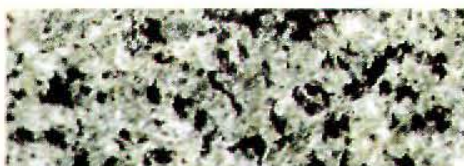

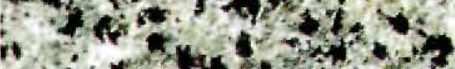

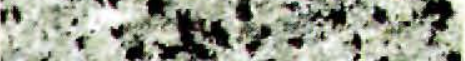
$x^{2}+x^{2} \sin ^{2}$

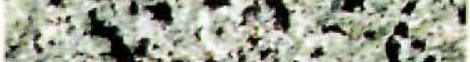

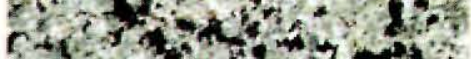

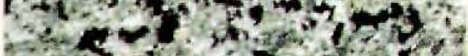



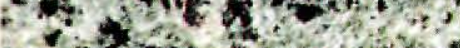
3raxy

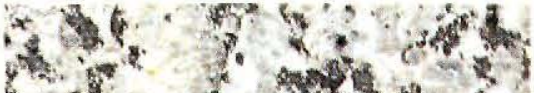
5. $x^{2}+y^{2}+w^{2}$



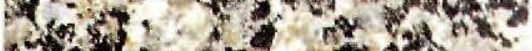

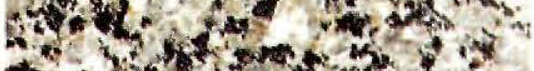

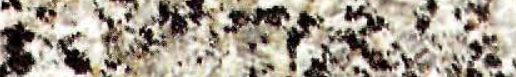

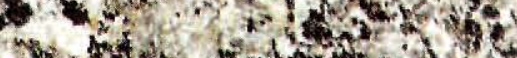

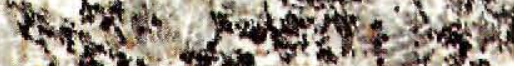

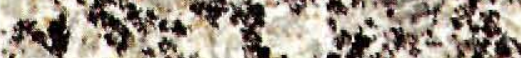

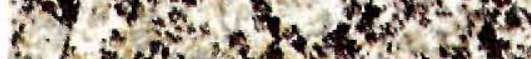

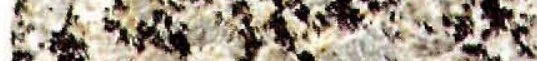

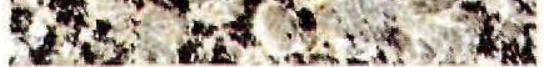

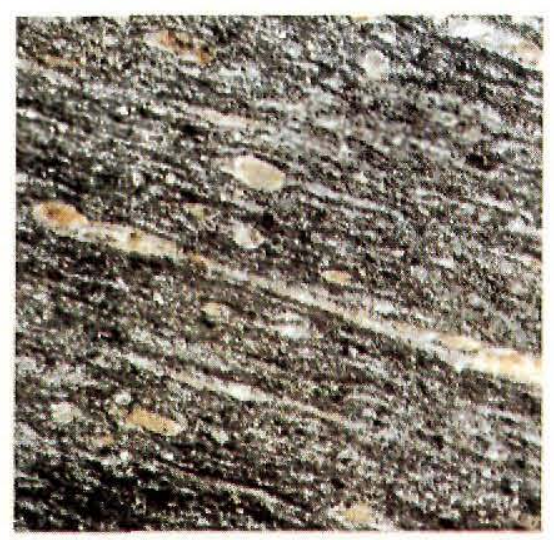



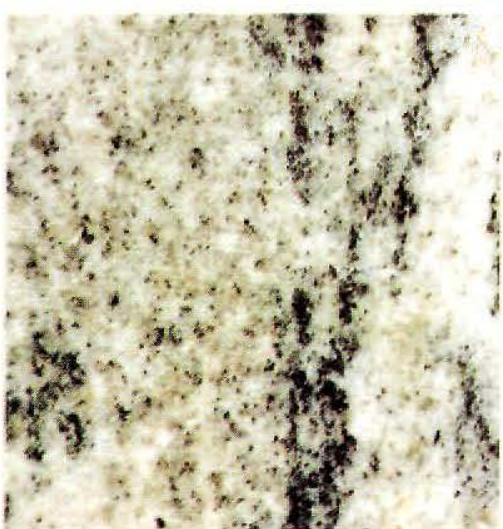


naq, dark hyperite near Sisimiut, and hypersthene diorite and granite from the Ammassalik district in East Greenland were also included in our evaluation.

These rocks may be grouped in three general categories, of which the two first groups are granites in the technical and commercial sense (i.e. hard and compact crystalline rocks where cutting with or without polishing is applied). They are: (1) strongly coloured and white rocks for gravestones in the high price category, (2) less conspicuously coloured (mainly grey) rocks in the lower price category for the building industry, and (3) Igaliko sandstone for pavements, building stones etc.

The most interesting rocks in the first category are anorthosites found at the head of Bjørnesund in the Qeqertarsuatsiaat/Fiskenæsset district south of Nuuk, which are composed almost entirely of white to pale buff plagioclase feldspar (Fig. 2). The anorthosites have attractive marble-like colours and textures and occur in large volumes, but our survey indicates that it would be difficult to produce sufficiently large blocks free from joints. Furthermore, the anorthosites are not homogeneous, and contain impurities in the form of bands of quartzo-feldspathic gneiss. Also, at the site we investigated, the topography is so steep that quarrying would soon become difficult.

The alkali granite from the Ilímaussaq intrusion near Narsaq has an attractive apple green colour (Fig. 2), which is however not considered sufficiently deep and intense to be suitable for gravestones; closely spaced joints prohibit the production of blocks larger than $c .1$ $\mathrm{m}^{3}$, which renders the rock unsuitable for building purposes. Access to the site by road from Narsaq also poses a problem.

The naujaite (Fig. 2), also from the Ilímaussaq intrusion, is a very unusual speckled, multicoloured redgreen-black-grey alkaline rock, which fluoresces under ultraviolet light. It is currently under investigation by the Swiss company Intergeo-Exploration. The rock is easily accessible on the south coast of the fjord Tunulliarfik, but it is weathered to a depth of several metres and the density of jointing is not immediately apparent.

Various granitic gneisses from several localities along the west coast of Greenland are either too heavily jointed (samples from Uummannaq), the occurrences are too small (as on the island Akullit between Aasiaat and Kangaatsiaq), or the colours too dull and dark to be considered of real interest in the second lower-price category. Examples from Akullit and north of Ilulissat are shown on Fig. 2. The granulite facies gneiss from Maniitsoq has a deep brown-green colour not commonly seen in ornamental stones (Fig. 2, floor in the town hall). Some consider the colour and texture very attractive, but opinion is divided. This rock was studied in detail at many localities within the town, both on natural outcrops and at fresh blasted surfaces, but it was concluded that there are too many joints and other defects to encourage production. Introduction of this unusual colour on the stone market would also be somewhat hazardous as it does not match any existing product.

The many varieties of Julianehåb granite are generally too jointed to be of any great interest; in any case many of the granite phases are very inhomogeneous. However, a locality of light grey, homogeneous granite at the fjord Tasermiut in the Nanortalik district (Fig. 2) might be quarryable.

Large (practically unlimited) occurrences of easily quarryable grey rapakivi granite (Fig. 2) without major defects were located on the island of Annikitsoq south of Aappilattoq in the southern part of Nanortalik district. The rock is very homogeneous and consists of rounded, very coarse, grey feldspar grains, sometimes with white rims, in a biotite-rich matrix. The ordinary grey colour places it in the lower price category for building purposes. The coarse grain size may be a negative aspect, reducing strength and increasing potential absorption of water. Occasional grains of allanite may locally cause rusty discolouration, although this was not a conspicuous defect on cut and polished surfaces. Other large rapakivi granite occurrences around Nanortalik very commonly contain very significant defects: numerous black inclusions and/or irregularly distributed light coloured veins, or large rusty spots.

Two types of Proterozoic intrusive rocks in the Ammassalik district, East Greenland, have potential for building purposes (Fig. 2). Brown homogeneous hypersthene diorite occurs in and around Ammassalik, and a light grey to brownish grey granite occurs in extensive outcrops in the northern part of Ammassalik $\emptyset$ with easy access by boat.

The Igaliko sandstone near Narsaq comes in the third category. It has an interesting and unusual but quite variable texture (Fig. 2) which is considered attractive by some people, but not by others. The rock consists almost entirely of well-cemented quartz, and is resistant to wear and friction. In certain horizons the sandstone has a natural cleavage suitable for the production of natural slabs a few centimetres thick, but closely spaced vertical joints limit the size of these slabs to a fraction of a square metre, and waste during production would be very large. In favour of production is their easy accessibility; a suitable site was located in an inland area $c .1$ $\mathrm{km}$ from the coast, where a road could easily be constructed. Also the demand for quarrying equipment would be modest, since it would not be necessary to handle large blocks. 


\section{Conclusions}

The ornamental stone project has revealed that West Greenland has only a limited potential for ornamental stones, mainly due to persistent regional joint systems. There are not many varieties of rocks which are sufficiently attractive to fetch a high price on the European market. However, a few types of rock deserve further consideration, notably anorthosite as a substitute for marble in gravestones, large deposits of grey rapakivi granite for building purposes, and the Igaliko sandstone. Further field studies are needed before samples from the Ammassalik district can be fully evaluated.

Acknowledgements. The authors are grateful to many people in Greenland who aided us during the field work especially at sea, and not least to N. C. Nielsen, Danstein A/S, for indispensable technical assistance and evaluation in Denmark. Published with permission from Grønlands Hjemmestyre.

\section{References}

Gothenborg, J. \& Garde, A. A. 1990: Naturstensprojekt 1990. Geologisk dokumentation for muligheder vedrørende produktion af natursten i Grønland. Unpubl. rep., Grønlands Hjemmestyre, 191 pp.

Kalsbeek, F. \& Garde, A. A. 1989: Descriptive text to 1:500 000 sheet 2, Frederikshåb Isblink - Søndre Strømfjord, 36 pp. Copenhagen: Grønlands Geol. Unders.

Kalsbeek, F., Larsen, L. M. \& Bondam, J. 1990: Descriptive text to 1:500 000 sheet 1, Sydgrønland, $36 \mathrm{pp}$. Copenhagen: Grønlands Geol. Unders.
A. A. G., Geological Survey of Greenland, Copenhagen.
C. B., CH-1410 Thierrens, Switzerland.
J. G., Mikkelborg Park 18, DK-2980 Kokkedal, Denmark.

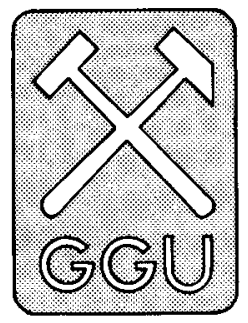

\title{
Geochemical mapping: distribution of gold, arsenic, antimony and tantalum in South Greenland
}

\author{
Agnete Steenfelt and Tapani Tukiainen
}

New graphics software utilising raster techniques has been developed at the Geological Survey of Greenland (GGU) during 1989 and 1990 for presentation of geochemical and geophysical areal data. The software is very suitable for the display of the regional variation of chemical elements as contoured colour maps of interpolated data. In this paper we show the distribution patterns for a few selected elements of economic interest, which have been determined in stream sediment samples collected in South Greenland in 1979. The implications of the new information for the mineral potential of the region are briefly discussed.

\section{Data acquisition}

The stream sediment samples were collected during a regional reconnaissance geochemical uranium exploration programme (Syduran) covering most of South Greenland (Fig. 1a; Armour-Brown et al., 1982). About
2300 samples were collected at an average density of 1 sample per $6 \mathrm{~km}^{2}$, and the $<0.1 \mathrm{~mm}$ grain size fraction was analysed at Ris $\varnothing$ National Laboratory, Denmark, for uranium by delayed neutron counting, and for 17 major and trace elements by radio-isotope energy dispersive X-ray fluorescence (Kunzendorf, 1979).

The uranium exploration and geological aspects of the results have been treated by Armour-Brown et al. (1983) and Steenfelt \& Armour-Brown (1988). The multi-element data were presented as geochemical maps by Armour-Brown et al. (1982) and by Olesen (1984), and they were treated statistically by ArmourBrown \& Olesen (1984). Steenfelt (in press) has dealt with the significance of the niobium, yttrium and uranium distributions.

Early in 1990 the stream sediment samples were reanalysed at Actlabs, Canada, for 34 elements by instrumental neutron activation. Only the gold and arsenic results of the new analyses have previously been 